\title{
The effect of dietary composition and of insulin on gluconeogenesis in rainbow trout (Salmo gairdneri)
}

\author{
BY C. B. COWEY, M. DE LA HIGUERA* AND J. W. ADRON \\ Institute of Marine Biochemistry, St Fitticks Road, Aberdeen AB1 $3 R A$
}

(Received 13 September 1976 - Accepted 2 November 1976)

1. The activities at $15^{\circ}$ of three gluconeogenic enzymes, D-fructose-1,6-diphosphate, 1-phosphohydrolase (EC 3.1.3.11), pyruvate carboxylase $(E C 6.4 .1 .1)$ and phosphoenolpyruvate carboxykinase (4.1.1.32), were determined in liver, kidney, gill and muscle of rainbow trout (Salmo gairdneri) given a commercial diet. The results indicated that liver and kidney are the main sites of gluconeogenesis.

2. Glucose formation from pyruvate was approximately $6 \mu \mathrm{mol} / \mathrm{h}$ per g wet weight at $15^{\circ}$ in liver slices of trout given a commercial diet.

3. Glucose diffusion space in trout was measured by the dilution principle after intravascular injection of a trace dose of [U-14 C]glucose. Glucose space was found to be $13.7 \%$ of the body-weight. Gluconeogenesis in vivo amounted to approximately $45 \mu \mathrm{mol} / \mathrm{kg}$ body-weight $\mathrm{per} \mathrm{h}$.

4. Intraperitoneally injected [U.14 C]alanine was quickly converted to glucose. Maximal incorporation of alanine into glucose occurred $6 \mathrm{~h}$ after alanine administration.

5. Rainbow trout given a high-protein diet gained in weight significantly during a 4-week period. Those given a high-carbohydrate diet did not make a significant weight gain over the same period. Gluconeogenesis from alanine was markedly reduced in fish given the high-carbohydrate diet. There was no significant difference in gluconeogenesis from alanine in fish given a high-protein diet and fish which were fasted for $21 \mathrm{~d}$.

6. Gluconeogenesis from alanine in trout was suppressed by intravenous injection of insulin. This effect was found both in trout given a high-protein diet and in fasted trout.

The natural diet of most omnivores probably contains sufficient carbohydrate to satisfy the needs of the whole animal. The natural diet of carnivores (and these include most species of fish) on the other hand contains little carbohydrate; those species of fish which have been cultured require diets of high protein content for optimal growth (Cowey, 1975). Complex carbohydrates are poorly assimilated by many fish (Singh \& Nose, 1967) and glucose is comparatively slowly oxidized by them (Cowey, Adron, Brown \& Shanks, 1975).

Nevertheless certain tissues in the fish may have a continual requirement for glucose which is used in these sites as a primary fuel; such tissues are brain, nervous tissue, erythrocytes and gonads. Thus the synthesis of glucose from non-carbohydrate precursors by gluconeogenesis may be an important pathway in the carnivorous fish given a normal diet.

Several species of teleost tolerate long periods of starvation in nature and hepatic gluconeogenesis is said to be enhanced at these times (Inui \& Ohshima, 1966; Larsson \& Lewander, 1973). The evidence for this is largely inferential, being based on reciprocal changes in muscle protein and tissue glycogen. In extreme instances such as the spawning migration of the Pacific salmon (Onchorhynchus nerka) liver glycogen content actually increases in the latter part of the migration, gluconeogenesis apparently exceeding the demand for glucose (Chang \& Idler, 1960); this may, however, be due to a low glucose demand rather than a high rate of gluconeogenesis. Direct evidence on the occurrence of gluconeogenesis in fish tissues was recently provided by Hayashi \& Ooshiro (1975) who showed that in the perfused liver of Anguilla japonica, a warm-water fish, gluconeogenesis from lactate proceeds at approximately the same rate as in perfused rat liver. However there is, as yet, no information available on the effect of dietary composition or of hormones on gluconeogenesis in fish.

\footnotetext{
* Present address: Catedra de Fisiologia, Universidad de Madrid, Madrid, Spain.
} 
The object of the present work was to study the tissue distribution of key gluconeogenic enzymes in rainbow trout (Salmo gairdneri) thereby throwing some light on which tissues are mainly involved in this process, to study the rate of gluconeogenesis in vitro (liver slices) and to study the effects of diet and of insulin on gluconeogenesis in the whole animal. The method used in the latter study was that of Friedmann, Goodman \& Weinhouse (1965) in which incorporation of intraperitoneally-injected [U-14 C]alanine into blood glucose was determined.

The results showed that gluconeogenesis from alanine proceeded at similar rates in trout which had either been starved or given a high-protein diet. Significantly lower rates of gluconeogenesis were found in trout given a high-carbohydrate-low-protein diet. Insulin significantly decreased the rates of gluconeogenesis in starved trout and in trout given a low-protein diet.

\section{EXPERIMENTAL}

\section{Fish and diets}

Rainbow trout of mean weight approximately $200 \mathrm{~g}$ were obtained from D. M. Brien, Almondbank, Perth. They had been reared on a commercial diet (Beta trout diet; Cooper Nutrition Products Ltd, Stepfield, Witham, Essex) containing (g/kg): 400 crude protein (nitrogen $\times 6 \cdot 25$ ), 45 oil and 45 fibre (Cooper Nutrition Products Ltd, personal communication). The trout were randomly distributed in four fibreglass tanks $(1.3 \times 0.9 \times 0.7 \mathrm{~m})$ ten fish/tank. Water from the City of Aberdeen domestic system was passed into an elevated reservoir tank where it was vigorously aerated and heated to $15 \pm 1^{\circ}$; water from this reservoir tank was distributed to the four fish tanks at the rate of $1.01 / \mathrm{min}$ per $\mathrm{kg}$ biomass fish. This water, passing from the reservoir tank, contained less than $0.7 \mu$ mol chlorine/l. The water was not recirculated and ran to waste after leaving the fish tanks.

The composition of the high-protein and high-carbohydrate diets are shown in Table 1. These diets were prepared as described previously (Cowey et al. 1975) except that after pelleting the moist pellets were freeze-dried. Trout were readily weaned to the experimental diets, fish in one of the tanks were given the high-protein diet, those in a second tank were given the high-carbohydrate diet while fish in the remaining tanks were given the commercial diet. The trout given commercial diet were used to determine the tissue distribution of key gluconeogenic enzymes and to study the rate of gluconeogenesis from pyruvate in liver slices. Later, trout which had been given commercial diet were fasted for $21 \mathrm{~d}$ before studying the rate of gluconeogenesis from alanine in the fasted animal.

Trout were fed manually to satiation three times/d (08.30, 12.00 and 16.30 hours) as described previously (Cowey et al. 1975). The fish were given the experimental diets for at least 4 weeks before measurement of the extent of gluconeogenesis.

\section{Tissue enzyme activities, liver-slice experiments and chemical methods}

The activities of three key gluconeogenic enzymes were determined in crude tissue extracts of gill, muscle, liver and kidney. Different fish (six individuals in each instance) were used for the assay of each enzyme. The tissues ( $1-2 \mathrm{~g}$ ) were homogenized in 10 vol. ice-cold extraction medium ( $50 \mathrm{~mm}$-Tris- $\mathrm{HCl}, 1 \mathrm{~mm}$-EDTA, $5 \mathrm{~mm}-\mathrm{MgCl}_{2}$ and $20 \mathrm{~mm}$-2-mercaptoethanol, pH 7.4). The homogenates were centrifuged at $1000 \mathrm{~g}$ for $10 \mathrm{~min}$. Phosphoenolpyruvate carboxykinase (EC 4.1.1.32) and pyruvate carboxylase $(E C 6.4 .1 .1)$ activities in the resulting supernatant fraction were estimated. For D-fructose-1,6-diphosphate 1phosphohydrolase (fructose diphosphatase; EC 3.1.3.11) activity the supernatant fraction at $1000 \mathrm{~g}$ was further centrifuged for $60 \mathrm{~min}$ at $100000 \mathrm{~g}$ and enzyme activity was estimated in the supernatant traction obtained. Phosphoenolpyruvate carboxykinase activity was measured as described by Pogson \& Smith (1975), pyruvate carboxylase activity 
Table 1. Composition ( $\mathrm{g} / \mathrm{kg}$ dry diet) of the diets given to rainbow trout (Salmo gairdneri)

$\begin{array}{lrc}\text { Component } & \begin{array}{c}\text { High-protein } \\ \text { diet }\end{array} & \begin{array}{c}\text { High-carbohydrate } \\ \text { diet }\end{array} \\ \text { White fish meal } & 872 & 150 \\ \text { Dextrin } & 0 & 550 \\ \text { Cod-liver oil } & 20 & 60 \\ \text { Maize oil } & 0 & 60 \\ \alpha \text {-cellulose } & 0 & 72 \\ \text { Vitamin premix* } & 28 & 28 \\ \text { Mineral mixture* } & 30 & 30 \\ \text { Binder† } & 50 & 50 \\ \text { Crude protein (nitrogen x 6.25) } & 600 & 100 \\ \text { Total lipid } & 81 & 131 \\ \text { Digestible carbohydrate } & 0 & 550 \\ \text { * Cowey, Pope, Adron \& Blair (1972). } & \\ \text { † Carboxymethyl cellulose (Cellofas; ICI Ltd, Stevenston, Ayrshire). } \\ \text { † Includes lipid in white fish meal. }\end{array}$

was assayed radiochemically as described by Saggerson (1974) and fructose diphosphatase activity was assayed by the method of Newsholme \& Crabtree (1970).

Substrates, co-enzymes and analytical enzymes used in the assays described were obtained from The Boehringer Corporation (London) Ltd, Lewes, Sussex. Other chemicals were analar or the best available grade.

Glucose formation from pyruvate (which gives high rates of gluconeogenesis in rat liver) by trout liver slices was measured as follows. Fish were first treated with phlorrhizin (Phase Separations Ltd, Queensferry, Clwyd) in order to lower liver glycogen levels because accurate measurement of carbohydrate formation is difficult unless the initial carbohydrate content of the liver is low. Trout ( $200 \mathrm{~g}$ live weight) were given intraperitoneally $50 \mathrm{mg}$ phlorrhizin freshly dissolved in $0.4 \mathrm{ml}$ butan-2,3-diol solution $(500 \mathrm{ml} / \mathrm{l})$. After $16 \mathrm{~h}$ the fish were killed by a sharp blow on the head, the liver was rapidly removed and rinsed in ice cold saline $(9 \mathrm{~g} \mathrm{NaCl} / 1)$. Liver slices $(0.3-0.4 \mathrm{~mm}$ thickness) were cut with a Mickle microtome (The Mickle Laboratory Engineering Co., Gomshall, Surrey) and dropped into ice-cold saline. After rinsing, four slices, chosen at random, were taken for initial glycogen estimation by potassium hydroxide digestion, ethanol precipitation and acidhydrolysis (Johnson \& Fusaro, 1966). Another four slices were used to measure initial glucose concentration. Remaining slices $(30-60 \mathrm{mg}$ wet weight) were placed individually in $25 \mathrm{ml}$ 'reacti' flasks (Pierce Chemical Co., Illinois, USA) containing $4 \mathrm{ml}$ incubation medium. The flasks were gassed with oxygen-carbon dioxide $(95: 5 ; \mathrm{v} / \mathrm{v})$ stoppered and incubated for 60-180 min in a 'shaking' water-bath (120 cycles/min) at $15 \pm 1^{\circ}$.

The incubation medium was a Krebs-Ringer bicarbonate medium modified by increasing the concentration of bicarbonate and reducing the concentration of $\mathrm{NaCl}$ to give a $\mathrm{pH}$ of 7.4 at $15^{\circ}$; it contained (mM): $120 \mathrm{NaCl}, 5 \cdot 1 \mathrm{KCl}, 1.3 \mathrm{MgSO}_{4}, 1.3 \mathrm{KH}_{2} \mathrm{PO}_{4}, 37.5 \mathrm{NaHCO}_{3}$, $2.7 \mathrm{CaCl}_{2}$. The concentration of pyruvate, when present, was $10 \mathrm{~mm}$. At the end of the incubation period the slices were rinsed, blotted, wet weighed (Cahn microbalance, Ventron Instrument Corporation, Paramount, California, USA) and their glycogen content determined. The protein in the incubation medium was precipitated with $0.5 \mathrm{ml} 3 \mathrm{M}$-perchloric acid and removed by centrifugation. The glucose content of the medium was then assayed by a glucose oxidase method (Krebs, Dierks \& Gascoyne, 1964). The amount of glucose produced by the slices was calculated as: (final concentration of 'slice' glycogen + 'medium' glucose)-(the initial content of glycogen + glucose in the slices). Net glucose formation 
from pyruvate was the difference between glucose production in slices incubated with pyruvate and those incubated without substrate.

Gluconeogenesis in the whole fish

L-[U-14 C]alanine of specific activity $170 \mathrm{mCi} / \mathrm{mmol}$ was obtained from The Radiochemical Centre, Amersham, Bucks. It was diluted with L-alanine to give a solution containing $2.5 \mu \mathrm{Ci} / \mathrm{mmol}$ in $1.0 \mathrm{ml}$ saline. Trout were fasted for $18 \mathrm{~h}$ (i.e. overnight) and lightly anaesthetized by placing them in water containing $0.1 \mathrm{~g}$ MS 222 (ethyl $\mathrm{m}$-aminobenzoic acid methane sulphonate; Sandoz Ltd, Basle, Switzerland)/l, for $2 \mathrm{~min}$. The fish were then given intraperitoneal injections of radioactive alanine at the rate of $25 \mu \mathrm{Ci} / \mathrm{kg}$ body-weight and returned to the experimental tank. After an appropriate interval (see p. 391) trout were again anaesthetized and a blood sample taken from the caudal vein, EDTA being used as the anticoagulant. The trout were then killed by cervical dislocation and a portion of the liver rapidly removed, weighed and treated for glycogen isolation as described for liver slices. A sample $(2.5 \mathrm{ml})$ of blood was deproteinized by the method of Somogyi (1945) and $5.0 \mathrm{ml}$ portions of the protein-free supernatant fraction were passed through columns $(6 \times 200 \mathrm{~mm})$ of mixed-bed resin (Amberlite, MB-3 analytical grade, BDH Ltd, Poole, Dorset). The column eluate together with washings was concentrated to dryness on a rotary film evaporator at $35^{\circ}$, taken up in deionized water and made to a convenient volume (usually $5.0 \mathrm{ml}$ ). The glucose content of this solution was measured by the glucose oxidase method and its radioactivity measured by adding $0.1 \mathrm{ml}$ sample to $10 \mathrm{ml}$ scintillation fluid (Instagel; Packard Instrument Co. Inc., Downers Grove, Illinois, USA) in a scintillation vial. The amount of radioactivity in the samples were estimated using a liquid-scintillation spectrometer (Tricarb model 3385; Packard Instrument Co. Inc.). The efficiency of counting was $78 \%(\mathrm{SD} \pm 1 \%)$. When glucose was isolated from the concentrated eluate by thin-layer chromatography on cellulose plates it was shown that more than $95 \%$ of the radioactivity was present in glucose.

In addition, results of preliminary tests showed that when mixtures of amino acids (alanine, aspartic acid, lysine) and glucose were passed through the Amberlite column, ninhydrin-positive material was not present in the eluate but glucose was recovered quantitatively from it.

The extent of the conversion of alanine to glucose was calculated from the relationship (Deodhar \& Mistry, 1969):

$$
\begin{aligned}
& \text { amount of dose glucose blood glucose }
\end{aligned}
$$

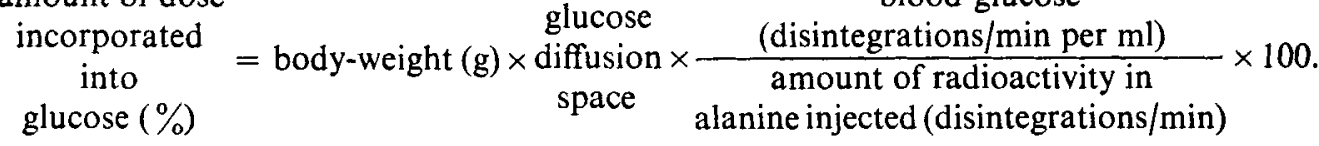

Alanine, rather than pyruvate, was used to compare gluconeogenic rates in whole trout given the different diets because the diets differed markedly in protein content so that an amino acid substrate appeared appropriate. At the same time alanine and pyruvate (used in the 'slice' experiments) are closely related metabolically and are rapidly interconverted.

Glucose space, i.e. the sum of compartments into which glucose apparently penetrates, was determined by the dilution principle (Holmes \& Donaldson, 1969) in which the concentration of radioactive glucose was determined in a series of plasma samples after intravenous administration of radioactive glucose. By extrapolation to zero time of the linear portion of the plot of radioactive glucose concentration $v$. period after injection, a theoretical value for the concentration of radioactive glucose at zero time was obtained, from which glucose diffusion space was calculated. This value for blood glucose radioactivity at zero time was an approximation as some glucose was being catabolized; however, the 


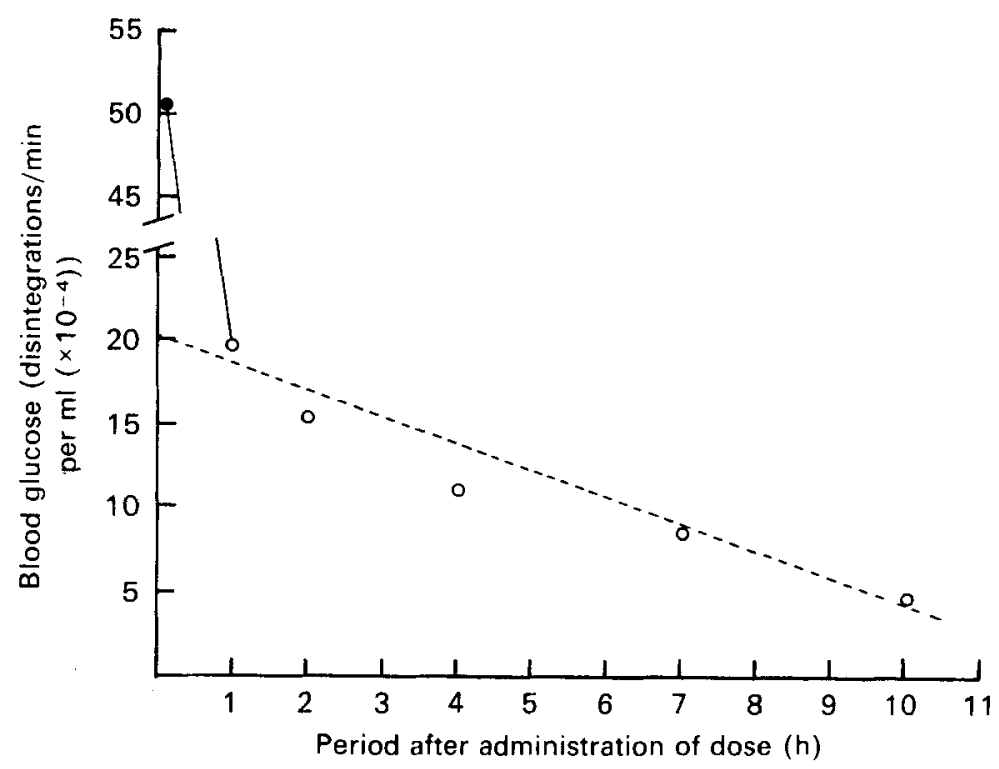

Fig. 1. Time-course of dilution of radioactive glucose in rainbow trout (Salmo gairdneri) after intravenous injection of $2.5 \mu \mathrm{Ci}\left[\mathrm{U}^{14} \mathrm{C}\right.$ ]glucose. Radioactivity in blood glucose (disintegrations/min per $\mathrm{ml}$ ) was determined in $0.1 \mathrm{ml}$ venous samples; each point is the mean value from six individuals. The theoretical dilution of isotope in the glucose diffusion space was obtained by extrapolation of the linear portion of the curve to zero time (- - ). For details of procedures, see p. 388.

error involved was likely to be small because glucose is very slowly metabolized by fish (Cowey et al. 1975), the half-life ( $t_{\frac{1}{2}}$ ) being $360 \mathrm{~min}$ (Fig. 1) (for carp (Cyprinus carpio) $t_{\frac{1}{1}}$ is $730 \mathrm{~min}$ (Mazeaud, 1973)).

Rainbow trout ( $200 \mathrm{~g}$ live weight) were injected intravascularly (caudal vein) with $2.5 \mu \mathrm{Ci}$ [U- ${ }^{14} \mathrm{C}$ ]glucose $(280 \mathrm{mCi} / \mathrm{mmol})$ in $0.3 \mathrm{ml}$ saline. The time-course of radioactive glucose dilution $(0 \cdot 1 \mathrm{ml}$ venous samples were taken with a micro-syringe and subjected to the ionexchange procedure described previously) is shown in Fig. 1.

Inspection of Fig. 1 indicated that the injected radioactive glucose had been distributed within $1 \mathrm{~h}$ in those compartments that it normally penetrates, because after this period radioactivity in the blood due to glucose decreased exponentially. It may be noted, parenthetically, that radioactive chloride takes $3.5 \mathrm{~h}$ to penetrate completely the chloride space in trout (Knox, Adron \& Cowey, unpublished results). Therefore to obtain the glucose diffusion space the decrease in radioactivity of blood glucose over the period 1-10 $\mathrm{h}$ was determined by least mean squares $(r-0.78 ; n 25 ; P<0.001)$ and the 'best fitting' line was extrapolated to zero time. The value thereby obtained for radioactivity in blood glucose at zero time was $20.2 \times 10^{4}$ disintegrations/min per $\mathrm{ml}$. As the activity of the glucose injected into a $200 \mathrm{~g}$ trout was $2 \cdot 5 \times 2 \cdot 22 \times 10^{6}$ disintegrations/min it follows that the glucose diffusion space is $13.7 \%$ body-weight (ten individuals). This compares with a mean value of $20.7 \%$ body-weight for glucose space in carp (Mazeaud, 1973) and with a value of $16.6 \%$ body-weight for sucrose space in Pseudoscarus guacamaia (Thorson, 1961). In comparable experiments in rats glucose space was taken to be $30 \%$ body-weight (Friedmann et al. 1965). 
Table 2. Activities (umol/g fresh weight per min) at $15^{\circ}$ of D-fructose-1,6-diphosphate phosphohydrolase (fructose diphosphatase; EC 3.1.3.11), pyruvate carboxylase (EC 6.4.1.1) and phosphoenolpyruvate carboxykinase (EC 4.1.1.32) in tissues of hatchery-reared rainbow trout (Salmo gairdneri)

\begin{tabular}{|c|c|c|c|c|c|c|}
\hline \multirow[b]{2}{*}{ Tissue } & \multicolumn{2}{|c|}{$\begin{array}{c}\text { Fructose } \\
\text { diphosphatase }\end{array}$} & \multicolumn{2}{|c|}{$\begin{array}{l}\text { Phosphoenolpyruvate } \\
\text { carboxykinase }\end{array}$} & \multicolumn{2}{|c|}{$\begin{array}{l}\text { Pyruvate } \\
\text { carboxylase }\end{array}$} \\
\hline & Mean & $\mathrm{SE}$ & Mean & $\mathrm{SE}$ & Mean & SE \\
\hline $\begin{array}{l}\text { Liver } \\
\text { Kidney } \\
\text { Gill } \\
\text { Muscle }\end{array}$ & $\begin{array}{l}1 \cdot 60 \\
0 \cdot 44 \\
0 \cdot 070 \\
0 \cdot 220\end{array}$ & $\begin{array}{l}0.13 \\
0.05 \\
0.008 \\
0.005\end{array}$ & $\begin{array}{l}1.32 \\
0 \cdot 33 \\
0 \cdot 010 \\
\text { not d }\end{array}$ & $\begin{array}{c}0.08 \\
0.04 \\
0.001 \\
\text { cted }\end{array}$ & $\begin{array}{l}0.79 \\
0.11 \\
0.040 \\
0.010\end{array}$ & $\begin{array}{l}0.028 \\
0.013 \\
0.007 \\
0.0008\end{array}$ \\
\hline
\end{tabular}

\section{RESULTS}

Tissue enzyme activities

The activities of fructose diphosphatase, phosphoenolpyruvate carboxykinase and pyruvate carboxylase in liver, kidney, muscle and gill of trout are shown in Table 2. These enzymes are regulatory for gluconeogenesis in mammalian liver (Newsholme \& Start, 1973) and as these tissues have a capacity for glycolysis (homogenates of these tissues will form lactic acid from glucose in the presence of added hexokinase (EC 2.7.1.1) (MacLeod, Jonas \& Roberts, 1963) the values obtained indicated that liver and to a lesser extent kidney are probably actively gluconeogenic tissues in trout under particular physiological conditions. The low activities found in gills rendered it unlikely, contrary to a recent suggestion (Driedzic \& Kicenuik, 1976), that this tissue is a major site of gluconeogenesis in trout.

\section{Gluconeogenesis in liver slices}

The time-course of glucose formation from pyruvate in liver slices from hatchery-reared trout is shown in Fig. 2. Each point represents the mean value for determinations on six fish. The livers of these trout contained between 25 and $40 \mathrm{mg}$ (glycogen + glucose)/g wet weight. Intraperitoneal injection of phlorrhizin reduced the carbohydrate content of the liver to $4.5 \mathrm{mg} / \mathrm{g}$ wet weight in $16 \mathrm{~h}$. Intravascular injection of phlorrhizin reduced the carbohydrate content to $9.8 \mathrm{mg} / \mathrm{g}$ wet weight while subdermal injections were without effect. Therefore intraperitoneal injections of phlorrhizin were given to all trout used in the 'slice' experiments.

In a $3 \mathrm{~h}$ period the rate of glucose formation from pyruvate by trout liver slices was reasonably linear (approximately $6 \mu \mathrm{mol}$ glucose formed/g wet weight per $h$ ). The results shown in Fig. 1 also permit an approximate estimate of glucose production in vivo. Thus $t_{\mathrm{l}}$ for glucose in trout is $6 \mathrm{~h}$, the blood glucose concentration in these fish is $3.95 \mathrm{mmol} / \mathrm{l}$ (Table 3), therefore in $6 \mathrm{~h}, 3.95 / 2 \mathrm{mmol}$ glucose/l blood are metabolized. As the glucose diffusion space is $13.7 \%$ of the body-weight then in a $100 \mathrm{~g}$ trout, $3.95 / 2 \times 13.7 / 1000 \mathrm{mmol}$ glucose are metabolized in $6 \mathrm{~h}$ i.e. $4.5 \mu \mathrm{mol} / \mathrm{h}$. The liver weight of a $100 \mathrm{~g}$ trout is approximately $1.3 \mathrm{~g}$ (Cowey, Knox, Walton \& Adron, 1977) and if glucose production in trout were entirely from the liver then hepatic gluconeogenesis would amount to approximately $3.5 \mu \mathrm{mol} / \mathrm{g}$ per $\mathrm{h}$. These two values for glucose formation are similar. This is surprisingly good as it is now apparent from mammalian studies that liver slices do not give adequate rates of gluconeogenesis and they have been superseded by isolated hepatocytes. It may be that measurement of glucose formation in slices containing glycogen is inherently unreliable because of the (variable?) contribution of glycogenolysis to glucose in the incubation 


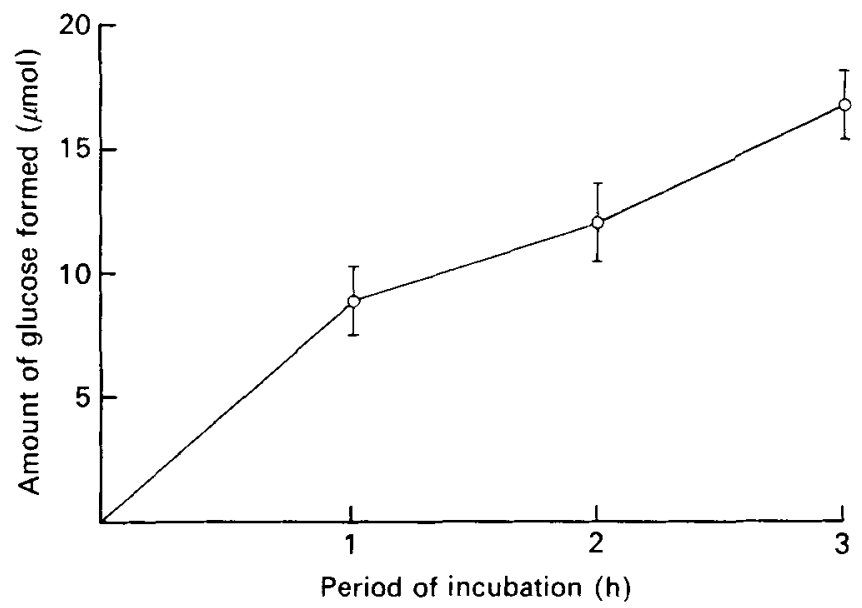

Fig. 2. Time-course of glucose formation $(\mu \mathrm{mol})$ from pyruvate in liver slices from hatchery-reared rainbow trout (Salmo gairdneri). Each point is the mean value from six individuals, with standard errors represented by vertical bars. For details of procedures, see p. 387 .

medium. However, recent measurements of glucose formation from pyruvate in the isolated perfused trout liver and in trout hepatocytes have given values of 10-12 $\mu \mathrm{mol}$ glucose formed/g liver per $\mathrm{h}$ (Walton, Adron \& Cowey, unpublished results) and it is now clear that gluconeogenesis in trout liver proceeds less rapidly than in the liver of omnivorous mammals.

\section{Weight gain on experimental diets}

There were marked differences in growth rate of trout given the two experimental diets. This was entirely in accord with expectation and with previous findings on the dietary protein requirement of trout (Satia, 1974). In the 4-week experimental period trout given the high-carbohydrate diet did not increase significantly in weight (mean \pm SE weight $(\mathrm{g}$ ) for ten fish: initial weight $203.6 \pm 3.2$; weight after 4 weeks $208.8 \pm 4.8$ ). Those given the high-protein diet made a significant $(P<0.05)$ gain in weight (mean \pm SE weight $(\mathrm{g})$ for ten fish: initial weight $201 \cdot 9 \pm 3 \cdot 1$; weight after 4 weeks $240 \cdot 4 \pm 4 \cdot 2$ ). The increase in blood glucose and liver glycogen in trout given the high-carbohydrate diet (Table 3 ) indicated that a high-carbohydrate intake produced hyperglycaemia in this fish.

\section{Effect of dietary composition on gluconeogenesis in whole fish}

Fig. 3 shows the time-course of incorporation of [U-14C]alanine into blood glucose in trout given the high-protein diet. Each point is the mean value obtained from experiments on four fish. Radioactivity was quickly incorporated into blood glucose, appreciable radioactivity being present in this molecule $2 \mathrm{~h}$ after injection of $\left[\mathrm{U}-{ }^{14} \mathrm{C}\right]$ alanine. The peak of radioactivity in blood glucose occurred $6 \mathrm{~h}$ after injection of the alanine, therefore in subsequent experiments the effects of different treatments on gluconeogenesis were studied $6 \mathrm{~h}$ after alanine injection. By comparison with trout, incorporation of ${ }^{14} \mathrm{C}$ from alanine into glucose in the rat was very rapid, reaching a peak in approximately $30 \mathrm{~min}$ (Friedmann et al. 1965). The relatively large alanine dose used $(1 \mathrm{mmol})$ was intended to minimize possible anomalous effects which may have resulted from variable dilutions of the radioactive alanine by endogenous alanine.

The conditions necessary to ensure that incorporation of a labelled substrate into glucose serves as a reliable guide to gluconeogenesis have been discussed by Friedmann, Goodman \& Weinhouse (1967). They point out that the specific activity of the substrate should not 


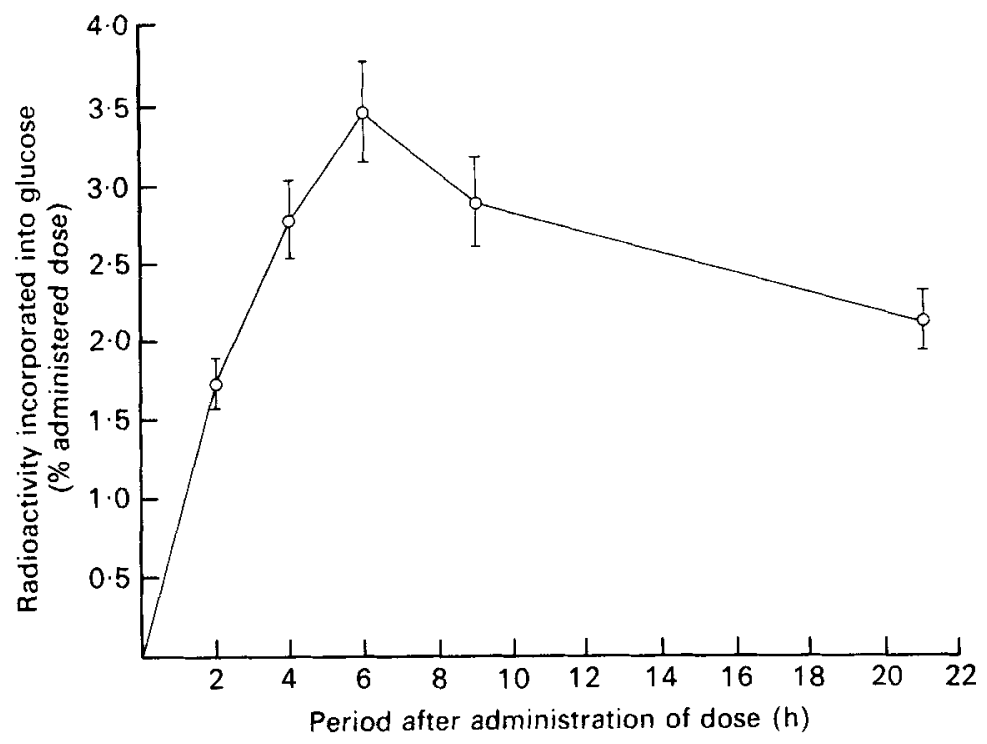

Fig. 3. Time-course of formation of radioactive glucose (\% administered dose) in blood of rainbow trout (Salmo gairdneri) given the high-protein diet (see Table 1) after intraperitoneal administration

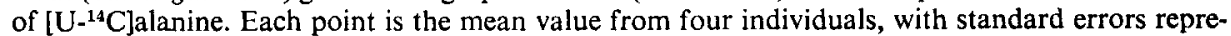
sented by vertical bars. For details of procedures, see p. 388 .

be unduly affected by the experimental conditions used and also that incorporation of radioactivity into glucose may be affected by changes in glucose utilization. While it is not possible to satisfy these points entirely it has been shown that incorporation of radioactivity from amino acids into expired $\mathrm{CO}_{2}$ and tissue protein in the fish was not affected by the dietary treatments used here (Cowey, 1975). Secondly the rate of utilization of glucose, measured over periods of several hours was not significantly changed by the dietary procedures used (Cowey et al. 1975). In addition the rate of glucose utilization in fish was low (cf. Fig. 1) and thus unlikely to influence the rate of incorporation of radioactive substrates.

The results in Table 3 show that the composition of the diet given to trout markedly affects the rate at which radioactivity from $\left[\mathrm{U}-{ }^{14} \mathrm{C}\right]$ alanine is incorporated into glucose. The highest rates of gluconeogenesis were found in trout given a high-protein diet and in trout subjected to prolonged starvation. Significantly lower rates of gluconeogenesis were found in trout given a high-carbohydrate-low-protein diet. In these experiments the amount of radioactivity found in liver glycogen was very low, irrespective of treatment, and glycogen formation was not a significant factor in gluconeogenesis over the time-period used.

The reduction in gluconeogenesis in the carnivorous trout by feeding a high-carbohydrate diet parallels very closely the diet-induced changes observed in an earlier study on rats (Friedmann et al. 1967). Glucose formation from $\left[3-{ }^{14} \mathrm{C}\right]$ pyruvate was highest in rats fasted for $48 \mathrm{~h}$ or given a high-protein diet, with a marked decrease in incorporation of pyruvate-C into blood glucose of rats given a high-carbohydrate diet.

\section{Effect of insulin}

Gluconeogenesis in mammals is subject to hormonal control, a major factor in this control being the circulating insulin level. Although, mainly on the basis of glucose tolerance tests, trout have been considered deficient in an endocrine mechanism to co-ordinately regulate carbohydrate metabolism (Palmer \& Ryman, 1972), recent results have in fact shown that immunoreactive insulin levels in trout plasma $(1 \cdot 6-6.8 \mathrm{ng} / \mathrm{ml})$ are of the same order of 
Table 3. Effect of dietary treatment on incorporation of radioactivity from $\left[\mathrm{U}-{ }^{14} \mathrm{C}\right]$ alanine into blood glucose and liver glycogen in rainbow trout (Salmo gairdneri)

(Mean values with their standard errors for six fish/group; gluconeogenesis from alanine is expressed as amount $(\%)$ of administered radioactivity detected in blood glucose or liver glycogen $6 \mathrm{~h}$ after administration of [U-41C]alanine)

Treatment $\uparrow$

Fasted

High-protein diet

High-carbohydrate diet

\begin{tabular}{|c|c|c|c|}
\hline \multicolumn{4}{|c|}{ Blood glucose } \\
\hline \multicolumn{2}{|c|}{$\mathrm{mmol} / \mathrm{l}$} & \multicolumn{2}{|c|}{$\begin{array}{l}\text { \% administered } \\
\text { radioactivity }\end{array}$} \\
\hline Mean & SE & Mean & $\mathrm{SE}$ \\
\hline $3.02^{*}$ & $0 \cdot 15$ & $2 \cdot 87$ & 0.34 \\
\hline 3.95 & 0.43 & 3.09 & 0.46 \\
\hline $5 \cdot 34^{*}$ & 0.57 & $0.46^{*}$ & 0.10 \\
\hline
\end{tabular}

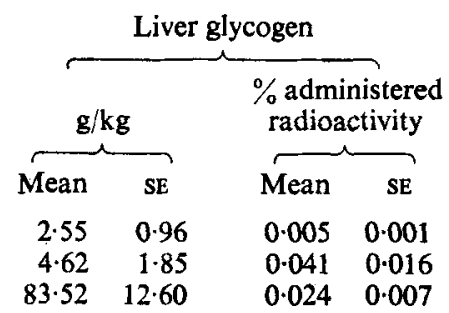

* Significantly different from each other or from the other two groups: $P<0.01$.

$\dagger$ For details of diets, see Table 1.

Table 4. Effect of insulin on incorporation of radioactivity from $\left[\mathrm{U}-{ }^{14} \mathrm{C}\right]$ alanine into blood glucose and liver glycogen in rainbow trout (Salmo gairdneri)

(Mean values with their standard errors for six fish/group; insulin (4 IU/ $\mathrm{kg}$ body-weight) given intravenously $2 \mathrm{~h}$ before administration alanine; control fish sham-injected with saline $(9 \mathrm{~g} \mathrm{NaCl} / \mathrm{l})$; gluconeogenesis from alanine is expressed as the amount $(\%)$ of the administered radioactivity detected in blood glucose or liver glycogen $6 \mathrm{~h}$ after administration of [U-14 C]alanine)

\begin{tabular}{|c|c|c|c|c|c|c|c|c|}
\hline \multirow[b]{3}{*}{ Treatment } & \multicolumn{4}{|c|}{ Blood glucose } & \multicolumn{4}{|c|}{ Liver glycogen } \\
\hline & \multicolumn{2}{|c|}{$\mathrm{mmol} / 1$} & \multicolumn{2}{|c|}{$\begin{array}{l}\% \text { administered } \\
\text { radioactivity }\end{array}$} & \multicolumn{2}{|c|}{$\mathrm{g} / \mathrm{kg}$} & \multicolumn{2}{|c|}{$\begin{array}{l}\% \text { administered } \\
\text { radioactivity }\end{array}$} \\
\hline & Mean & SE & Mean & SE & Mean & SE & Mean & $\mathrm{SE}$ \\
\hline $\begin{array}{l}\text { Fasted, control } \\
\text { Fasted + insulin } \\
\text { High-protein diet, control } \\
\text { High-protein diet + insulin }\end{array}$ & $\begin{array}{l}3 \cdot 0 \\
0 \cdot 81^{*} \\
3 \cdot 1 \\
0 \cdot 85^{*}\end{array}$ & $\begin{array}{l}0.24 \\
0.14 \\
0.17 \\
0.12\end{array}$ & $\begin{array}{l}3 \cdot 34 \\
0 \cdot 48^{*} \\
2 \cdot 84 \\
0 \cdot 26^{*}\end{array}$ & $\begin{array}{l}0.19 \\
0.04 \\
0.42 \\
0.07\end{array}$ & $\begin{array}{r}0.54 \\
1.98 \\
4 \cdot 38 \\
12 \cdot 80\end{array}$ & $\begin{array}{l}0.27 \\
0.95 \\
1.25 \\
1.69\end{array}$ & $\begin{array}{l}0.042 \\
0.228 \\
0.005 \\
0.079\end{array}$ & $\begin{array}{l}0.023 \\
0.136 \\
0.002 \\
0.039\end{array}$ \\
\hline
\end{tabular}

* Significantly different from corresponding control group: $P<0.01$.

$\uparrow$ For details of diet, see Table 1 .

magnitude as those in omnivorous mammals (Thorpe \& Ince, 1976). It was therefore of interest to see whether insulin treatment of fasted or protein-fed trout reduced the rate of gluconeogenesis. The effects of intravenous injections of insulin ( $4 \mathrm{IU} / \mathrm{kg}$ body-weight) in such trout are shown in Table 4. In both groups insulin treatment reduced gluconeogenesis to very low levels.

\section{DISCUSSION}

The carbohydrate intake of omnivorous mammals is normally adequate to meet their demand for glucose, and gluconeogenesis probably only becomes of quantitative importance when dietary carbohydrate intake is restricted or during starvation. The glucose requirement of carnivorous fish is not accurately known but it has been suggested that gluconeogenesis may be essential in carnivorous animals on a normal (? natural) diet (Newsholme \& Start, 1973). The rate of glucose formation $(6.0 \mu \mathrm{mol} / \mathrm{g}$ per $\mathrm{h}$ from pyruvate in liver slices and $45 \mu \mathrm{mol} / \mathrm{kg}$ per $\mathrm{h}$ in the whole animal) found in trout in the present work is lower than those reported for omnivorous mammals (approximately $60 \mu \mathrm{mol} / \mathrm{g}$ fresh liver per $\mathrm{h}$ from pyruvate, depending on dietary treatment (Newsholme \& Start, 1973)). It may be inferred that 


\section{C. B. Cowey, M. De la Higuera and J. W. Adron}

the requirement for glucose of the trout is low because of the comparatively low rates of gluconeogenesis.

The reduction in gluconeogenesis from alanine in trout given a high-carbohydrate diet is an adaptive response to the metabolic needs of the animal. The activities of many tissue enzymes in mammals are now known to vary in response to gross changes in dietary intake. Instances of similar effects in fish are less common although histidase $(E C 4.3 .1 .3)$ and urocanase $(E C 4.2 .1 .49)$ activities in carp liver adapt to changes in dietary protein and histidine intake (Sakaguchi \& Kawai, 1970). Changes in the activities of several enzymes in the gluconeogenic pathway could account for the response to alterations in the level of carbohydrate and protein in the diet, evidence that phosphoenolpyruvate carboxykinase and fructose disphosphatase activities are affected by such a change have been presented (Cowey et al. 1977).

Another factor in the adaptive response to changes in dietary composition is the consequent alteration in substrate availability. In the fasting rat the main gluconeogenic substrates are lactate, glycerol and amino acids; the same materials are likely to constitute the main gluconeogenic substrates in fish given a high-protein diet, with amino acids the most important substrate because of their quantitative preponderance in the diet. When trout are given a low-protein diet the concentrations of amino acids in the plasma are markedly reduced (Cowey et al. 1977) and this lowered substrate availability probably contributes to the adaptive decrease in gluconeogenesis found in the present experiments.

In the starving fish the sequence in which gluconeogenic substrates are utilized changes during the starvation period. In the spawning migration of Pacific salmon fat reserves from the viscera and the muscle are used preferentially to provide energy (Chang \& Idler, 1960) so that in the first part of the spawning migration glycerol is probably the main gluconeogenic substrate; later, tissue protein is used to provide energy and amino acids are then likely to be the main precursors of glucose. The normal cruising, swimming movements of the fish are made by the small amount of red (aerobic) muscle present in the musculature, the bulk of the white (glycolytic) muscle is used mainly in escape reactions and possibly catching of prey. It is therefore probable that lactate is of less quantitative importance as a gluconeogenic substrate in fish than is the situation in omnivorous mammals.

It has been shown that insulin (in pharmacological rather than physiological doses) reduces gluconeogenesis in trout. Moreover, it is now evident that plasma insulin levels in fish are of a similar order to those occurring in mammals (Thorpe \& Ince, 1976) but the chemical or physiological signals involved in insulin release in fish are unknown. Present evidence is that glucose is not a factor (Tashima \& Cahill, 1968; Thorpe \& Ince, 1976) and insulin appears to play little part in glucose homoeostasis in fish. Insulin does, however, markedly increase the rate of amino acid incorporation into fish muscle protein (Tashima \& Cahill, 1968) and reduce plasma amino acid levels (Cowey et al. 1977). This latter effect must contribute to the observed reduction in gluconeogenesis after insulin treatment.

The ability of trout to exert metabolic control over gluconeogenesis contrasts with their inability to control blood glucose concentration closely. The latter defect can no longer be ascribed to an inadequate endocrine mechanism (Palmer \& Ryman, 1972). Blood glucose in omnivorous and herbivorous mammals (other than ruminants) is controlled by the liver which removes glucose from the blood by virtue of an inducible glucokinase (EC 2.7.1.12). No glucokinase activity could be found in trout liver even after prolonged feeding of diets high in carbohydrate (Cowey et al. 1977). The low glucose-phosphorylating capacity of trout liver provides an explanation of their inability to metabolize large amounts of dietary carbohydrate. It is also of interest that some terrestrial carnivores, such as the cat, are not known to possess a glucokinase (Ballard, 1965). 
The authors thank Dr M. J. Walton both for allowing them to quote unpublished results on gluconeogenesis in trout hepatocytes and isolated perfused liver and for his comments on the typescript. They also thank Dr P. T. Grant for helpful criticism during the course of the work.

\section{REFERENCES}

Ballard, F. J. (1965). Comp. Biochem. Physiol. 14, 437.

Chang, V. M. \& Idler, D. R. (1960). Can. J. Biochem. Physiol. 38, 553.

Cowey, C. B. (1975). Proc. Nutr. Soc. 34, 57.

Cowey, C. B., Adron, J. W., Brown, D. A. \& Shanks, A. M. (1975). Br. J. Nutr. 33, 219.

Cowey, C. B., Knox, D., Walton, M. J. \& Adron, J. W. (1977). Br. J. Nutr. 38, 463.

Cowey, C. B., Pope, J. A., Adron, J. W. \& Blair, A. (1972). Br. J. Nutr. 28, 447.

Deodhar, A. D. \& Mistry, S. P. (1969). Archs Biochem. Biophys. 131, 507.

Driedzic, W. R. \& Kicenuik, J. W. (1976). J. Fish Res. Bd Can. 33, 173.

Friedmann, B., Goodman, E. H. \& Weinhouse, S. (1965). J. biol. Chem. 240, 3729.

Friedmann, B., Goodman, E. H. \& Weinhouse, S. (1967). J. biol. Chem. 242, 3620.

Hayashi, S. \& Ooshiro, Z. (1975). Bull. Jap. Soc. Scient. Fish. 41, 201.

Holmes, S. N. \& Donaldson, E. M. (1969). In Fish Physiology, p. 1 [W. S. Hoar and D. J. Randall, editors]. New York: Academic Press.

Inui, Y. \& Ohshima, Y. (1966). Bull. Jap. Soc. Scient. Fish. 32, 492.

Johnson, J. A. \& Fusaro, R. M. (1966). Analyt. Biochem. 15, 140.

Krebs, H. A., Dierks, C. \& Gascoyne, T. (1964). Biochem. J. 93, 112.

Larsson, A. \& Lewander, K. (1973). Comp. Biochem. Physiol. 44A, 367.

MacLeod, R. A., Jonas, R. E. E. \& Roberts, E. (1963). Can. J. Biochem. Physiol. 41, 1971.

Mazeaud, F. (1973). Recherches sur la régulation des acides gras libres plasmatiques et de la glycéruie chez les poissons. PhD Thesis, University of Paris.

Newsholme, E. A. \& Crabtree, B. (1970). FEBS Lett. 7, 195.

Newsholme, E. A. \& Start, C. (1973). Regulation in Metabolism, London: John Wiley \& Sons.

Palmer, T. N. \& Ryman, B. E. (1972). J. Fish Biol. 4, 311.

Pogson, C. I. \& Smith, S. A. (1975). Biochem. J. 152, 401.

Saggerson, E. D. (1974). Biochem. J. 140, 211.

Sakaguchi, M. \& Kawai, A. (1970). Bull. Jap. Soc. Scient. Fish 36, 783.

Satia, B. P. (1974). Progve. Fish Cult. 36, 80.

Singh, R. P. \& Nose, T. (1967). Bull. Freshwat. Fish Res. Lab., Tokyo, 17, 21.

Somogyi, M. (1945). J. biol. Chem. 160, 69.

Tashima, L. \& Cahill, G. F. (1968). Gen. Comp. Endocrinol. 11, 262.

Thorpe, A. \& Ince, B. W. (1976). Gen. Comp. Endocrinol. 30, 332.

Thorson, T. (1961). Biol. Bull. 120, 238. 